\title{
OHSAS 18001: Sustainable Construction
}

\author{
Mohd Arif Marhani, Hamimah Adnan, Faridah Ismail \\ Faculty of Architecture, Planning and Surveying, \\ Universiti Teknologi MARA, Shah Alam 40450, Malaysia \\ arif2713@salam.uitm.edu.my, hamimah689@salam.uitm.edu.my, \\ farid346@salam.uitm.edu.my
}

\begin{abstract}
OHSAS 18001 was proposed to promote an organisation manages occupational health and safety (OH\&S) risks and further improved work operations. However, the positive efforts by the government of Malaysia to improve the implementation, use and acceptance level of OHSAS 18001 are still not remarkable. Hence, the objectives of this paper are to determine the level of acceptance and to establish the best alternative practice in implementing OHSAS 18001. Questionnaire surveys were used as the research method. It is hoped that the implementation of OHSAS 18001 can stimulate the atmosphere of safety culture towards sustainable construction in the Malaysian construction industry.

Keywords: Acceptance; OHSAS 18001; Sustainable Construction; Malaysian Construction Industry

eISSN 2514-751X @ 2018. The Authors. Published for AMER ABRA cE-Bs by e-International Publishing House, Ltd., UK. This is an open-access article under the CC BY-NC-ND license (http://creativecommons.org/licenses/bync-nd/4.0/). Peer-review under responsibility of AMER (Association of Malaysian Environment-Behaviour Researchers), ABRA (Association of Behavioural Researchers on Asians) and cE-Bs (Centre for EnvironmentBehaviour Studies), Faculty of Architecture, Planning \& Surveying, Universiti Teknologi MARA, Malaysia.

DOI: https://doi.org/10.21834/aje-bs.v5i17.46
\end{abstract}




\subsection{Introduction}

OHSAS 18001 is an Occupation Health and Safety Assessment Series for health and safety management systems. It is intended to promote an organisation to control occupational health and safety risks. The aim of OHSAS 18001 is to assist organisations in managing and controlling their health and safety risks in addition to improving their $\mathrm{OH} \& S$ performances.

While OHSAS 18001 is not a legal requirement, it is a recognised specification that structures the implementation of an effective health and safety management system. Hence, organisations registered to OHSAS 18001 are having an approach to verify the employees that they are on the right track and that they are using a structured process to protect their safety and others (OHSAS 18001, 2011). In Malaysia, there are three basic legislation Acts that regulate the OH\&S of works in the construction industry, namely: The Occupational Safety and Health Act 1994 (Act 514) (OSHA), The Factories \& Machineries Act 1967 (Act 139) (FAMA) and The Construction Industry Development Act 1994 (Act 520) (CIDB).

Although safety regulations provided by OSHA 1994 are remarkably detailed, a level of awareness and practicability of it for over the last five (5) years is lower than expected (Abdul Hamid et al., 2003). Therefore, the application of "effective" management can lead to safer systems of construction and lower the incidence of injuries and work-related diseases (Davies and Tomasin, 1996). To reduce the accident or incident level and eventually cut losses, it is necessary to ensure that safe working practice is being observed (Ahmad, 2000).

Besides, in Malaysia, legislation to the $\mathrm{OH} \& \mathrm{~S}$ issues is deemed sufficient but legislative enforcement is still lacking. To rectify this situation, the practical approach shall be to raise awareness of construction companies regarding the importance of $\mathrm{OH} \& \mathrm{~S}$ and implementation of occupational safety and health management system for the construction industry in Malaysia (Omran et al., 2008).

\subsection{Issue Statement}

According to the statistics reported by the Social Security Organisation (SOCSO), the numbers of fatality cases in the construction industry are amongst the highest in the 10 categorised industries in Malaysia (SOCSO, 2005). The rate of fatality cases in the construction industry in Malaysia was of more than three times of other workplaces; it was $3.3 \%$ in the construction industry as compared to other workplaces of $1.1 \%$ such as manufacturing and mining and quarrying (SOCSO, 2000). According to statistics compiled in CIDB's report (2010), there were over 140 crane accident deaths in 2004.

An unsafe act is a violation of a known or accepted safety procedure, which could allow the occurrence of an accident. Unsafe practices or acts are often seen in every construction project all over the world. Furthermore, other examples would be working without authority, using equipment inadequately, unsafe loading and fixing (Bashir, 2008).

Through OHSAS 18001, it is the responsibility of management to provide a safe and conducive working environment where the employees will be able to provide better to the organisation. Management should emphasise on finding a management strategy and resolves to reduce the rate of accident occurrence, which could lead to saving lives at the construction site. But, are they aware of it and do they implement it, especially to all of the 
Malaysian contractors?

\subsection{Sustainable Construction}

Sustainable construction could be defined as the creation and responsible management of a healthy built environment based on resource efficiency and ecological principles. It is widely used to describe the importance of sustainable development in the construction industry. Therefore, sustainable construction could be best described as a subset of sustainable development, which encircles matters such as tendering, site planning and organisation, material selection, recycling, and waste minimisation (Langston and Ding, 2001 cited in Khalfan, 2002). To relate the sustainable construction with OHSAS 18001, the six (6) principles needed to highlight the effectiveness of the entire construction process during the pre-construction phase, construction phase and post-construction. Based on Khalfan (2002), the six (6) principles to achieve success in sustainable construction process specifically for safety level must consist of:-

- Minimisation of resource consumption;

- Maximisation of resource reuse;

- Use renewable and recyclable resources;

- $\quad$ Protect the natural environment; Create a healthy and non-toxic environment; and

- $\quad$ Pursue quality in creating the built environment.

Through the above principles, it showed that peoples' concerns about building performance in their construction projects and concerns to achieve the sustainability, occupants demand to have priority in terms of comfortability to use and utilise the facilities and services as it must be fit for the purpose of the user (Khalil et al., 2012).

\subsection{OHSAS 18001 and Its Elements}

Based on OHSAS 18001:1999 (1999), its specification gives an occupational health and safety management system (OHSMS) to enable an organisation managing their risks and improving their performance.

There are five (5) key elements of OHSAS 18001 which are used as OHSMS implementation tools. These core elements are shown in Figure 1.

\subsection{Methodology}

The execution of this research consists of four (4) main stages, namely: identifying research issues, data collection, data analysis and writing. The quantitative method was conducted to gather the information required because of the versatility they provide in the examination of social and economic phenomena. The quantitative method used known as questionnaire surveys which were sent to 100 contractors through the postal distribution. The study area is focused in Selangor and Kuala Lumpur. Besides, these areas selected due to the peak of construction projects and the main centre of Malaysian business, especially in Kuala Lumpur. 
Overall, thirty per cent (30\%) of contractors replied, and the reason for non-response could be the changing of the company's address or no attention to participate in this survey. Statistical analysis of the data was done using Microsoft Excel 2010 and all survey participants will remain anonymous.

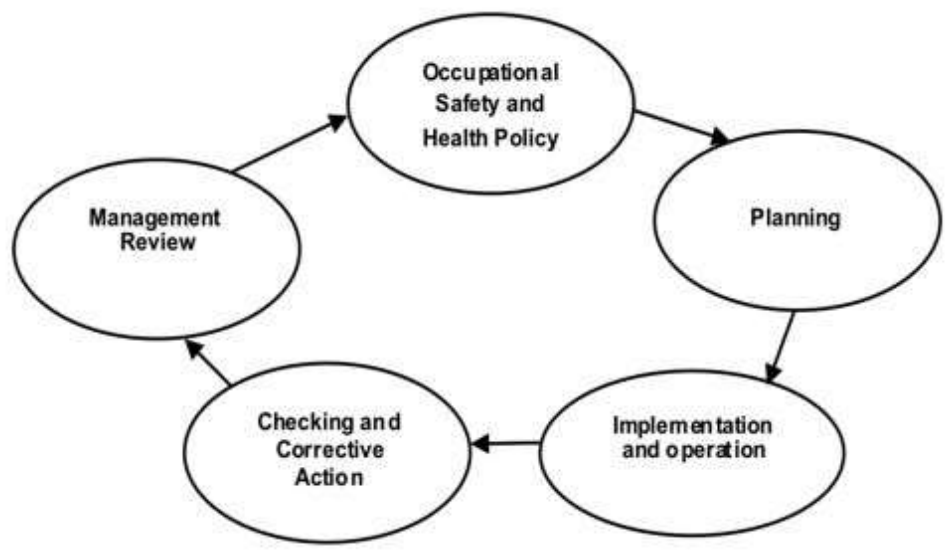

Figure 1: Five key elements of OHSAS 18001

(Source: adopted and modified from ICMR Bulletin (2003))

\subsection{Results}

This section will present the results that emerged from the study. These results summarised the data collected for the surveys. The sample of the study was selected from a hundred (100) Universiti Teknologi MARA (UiTM) contractors registered with the Development Office UiTM. However, due to time constraint and the attitude of the respondents, only 30 questionnaires have been filled. All these 30 answered questionnaires represent $30 \%$ of the survey sample for statistical analysis.

\section{Section A: Background of respondents}

This section comprised of eight (8) questions. Most of the respondents were general contractors (building/civil) while the minority respondents were subcontractors (building/civil) involved in construction projects. The majority of respondents from questionnaire surveys have work experience in construction around $6-10$ years at $43 \%$, constructed more than 6 10 numbers of projects based on OHSAS 18001 at $66 \%$ and have more than 30 workers or $40 \%$ in their companies. Besides, the majority of them have health and safety department in their projects at $63 \%$. Based on the questionnaire analysis, the respondents followed the safety guidelines and requirements based on OHSAS 18001 during the construction process of their companies at $67 \%$ and did not implement and certify OHSAS 18001 in their company at $47 \%$, which resulted, classified as low level of acceptance for OHSAS 18001 . The reasons not to implement OHSAS 18001 were no enforcement by the government, inadequate budget, company policy and lack of information. However, the highest implemented and 
certified of OHSAS 18001 in construction projects was around $1-2$ years and only $27 \%$ of those companies who have implemented the OHSAS 18001.

\section{Section B: Understanding OHSAS 18001 in the construction industry}

This section comprised of ten (10) questions. Most of the respondents understood about the implementation of OHSAS 18001 especially for those applied in their construction project at $83 \%$. The majority of the companies provided necessary protection and safety to the public or their properties during the construction process at $100 \%$. All respondents provided PPE for workers or any other person involved in construction to ensure the safety is under control and reduces the accidents to the workers and other parties. The types of PPE provided by the contractor companies from questionnaire surveys were as follows:-

- $\quad$ Safety Helmet (100\%)

- $\quad$ Safety Footwear and Safety Gloves (100\%)

- $\quad$ Goggles and Face Shield (63\%)

- $\quad$ Safety Harness $(53 \%)$

- $\quad$ Ear Muffs (30\%)

- $\quad$ Respirator (17\%)

- Others (3\%)

Only $70 \%$ respondents provided adequate PPE. Although, most respondents provided a safety plan before commencing the construction process at $90 \%$ and $83 \%$ respondents conducted the safety-training programme to their workers. Besides, $70 \%$ respondents have a safety officer in their construction project. Most of the respondents kept records of all accidents at $93 \%$. Based on the analysis done, if there is a serious accident happened on the site, the respondents will stop working until the risk of accident cleared by the 13 responds, followed with continuing work and study the cause by the 11 responds and to review the construction procedure's safety by the nine responds.

\section{Section C: Awareness in implementing OHSAS 18001}

Table 1: Level of awareness on acceptance of OHSAS 18001

\begin{tabular}{ll}
\hline OHSAS 18001 & $\begin{array}{l}\text { RATING } \\
\text { SCALE }\end{array}$ \\
\hline Element No. 1: OH\&S Policy & Important \\
\hline Element No. 2: Planning & Most Important \\
\hline Element No. 3: & Most Important \\
Implementation And & \\
Operation & \\
\hline $\begin{array}{l}\text { Element No. 4: Checking And } \\
\text { Corrective Action }\end{array}$ & Most Important \\
\hline Element No.5: Management & Important \\
Review & \\
\hline
\end{tabular}

This part analysed enforcement awareness by implementing OHSAS 18001 in the Malaysian construction industry. Respondents need to rank their preference of appropriate based on the stated scale. This part will be analysed by using both percentage and index methods. 
Table 1 summarised this section from the contractor companies' findings.

\section{Section D: Suggestions to improve OHSAS 18001}

This part analysed the suggestions to improve OHSAS 18001, especially to the contractors. Respondents need to rank their suggestions based on the stated scale. This part will be analysed by using both, percentage and index methods. Table 2 summarised the results.

Table 2: Suggestions by contractors to improve OHSAS 18001

\begin{tabular}{|clc|}
\hline \multicolumn{1}{c}{$\begin{array}{c}\text { SUGGESTIONS TO IMPROVE } \\
\text { OHSAS 18001 AMONG } \\
\text { CONTRACTORS }\end{array}$} & $\begin{array}{c}\text { RATING } \\
\text { SCALE }\end{array}$ \\
\hline 1 & $\begin{array}{l}\text { Do supervision with competent people } \\
\text { during Construction works }\end{array}$ & $\begin{array}{c}\text { Strongly } \\
\text { Agreed }\end{array}$ \\
\hline 2 & $\begin{array}{l}\text { Ensure the construction processes to } \\
\text { comply with the Code of Practice which } \\
\text { is standard and stated in OHSAS }\end{array}$ & $\begin{array}{c}\text { Strongly } \\
\text { Agreed }\end{array}$ \\
& 18001 & \\
\hline 3 & $\begin{array}{l}\text { Promote campaign such as a road } \\
\text { show, exhibition and etc. to promote } \\
\text { awareness of OHSAS 18001 in } \\
\text { construction safety }\end{array}$ & $\begin{array}{l}\text { Strongly } \\
\text { Agreed }\end{array}$ \\
\hline 4 & $\begin{array}{l}\text { Collaboration of inter ministry to amend } \\
\text { legislation for the benefit of construction } \\
\text { and form an alliance to share } \\
\text { experience }\end{array}$ & $\begin{array}{l}\text { Strongly } \\
\text { Agreed }\end{array}$ \\
\hline \multicolumn{1}{c}{ Overall } & $\begin{array}{c}\text { Strongly } \\
\text { Agreed }\end{array}$ \\
\hline
\end{tabular}

From the Table 2 also, it showed that the suggestions to improve OHSAS 18001 were agreed by all respondents to increase the level of acceptance of OHSAS 18001 in the Malaysian construction industry. Furthermore, respondents also suggested that:-

- The contractor must provide training to all workers and parties involve in site. This is essential to provide the knowledge about safety and how to overcome any accident happens during construction. Furthermore, it will expose them to the OHSAS 18001.

- $\quad$ Government collaborates with private agencies to promote the campaign and doing the seminar to improve the level of awareness and importance of OHSAS 18001 in a construction site. With this, the construction parties involved in the construction industry will collaborate to achieve the maximum utilisation of OHSAS 18001 in Malaysia construction industry.

- $\quad$ The government should have authority over the parties involved in construction projects including manufacturer, constructor, designer, financial institution and the transporters to ensure they play their respective roles in the successful implementation of OHSAS 18001.

- $\quad$ The government must standardise a proper OHSMS rather than leave it open for companies to follow, whether to follow OHSAS 18001 or MS 1722. It must make adopting a proper OHSMS likes OHSAS in law and not made it optional. Besides, to 
ensure the construction processes comply with the Code of Practice, which is standard and stated in OHSAS 18001.

\subsection{Discussion}

As a discussion manner, the respondents' ideas to implement the OHSAS 18001 will be available for practice in the Malaysian construction industry. By providing valuable information and guidelines to contractors within their organisation as well as to the industry, it is significant as a framework to the existing and future Malaysian contractors in guiding them on implementing the OHSAS 18001. As a result, the implementation of OHSAS 18001 as the future framework need to be enforced through the few recommendations made as below:-

- $\quad$ The client must ensure that the contractor involved in their construction must have their health and safety department.

- The contractor must ensure all safety procedures to be implemented on the site and conduct are always checking the site to ensure all parties involved follow the procedures.

- $\quad$ Malaysian contractors must ensure the contractor to establish a safety culture at the workplace by doing regular supervision.

- $\quad$ The contractor must provide training for all workers and parties involve in site. This is necessary to provide sufficient knowledge about the safety and ways to overcome any accident that may or may not occur during construction. Thus, they need to send a report to the client to convince the level of safety to be undertaken for their project.

- $\quad$ The government must standardise a proper OHSMS rather than leave it open for companies to choose, whether to follow OHSAS 18001 or MS 1722. Therefore, contractors will be obedient to these elements since it stated in the law.

- $\quad$ Contractors can build an environment of participation between project management and workers since it can also be the key to ensuring the effectiveness of OHSAS 18001 in the work site.

- $\quad$ Contractors shall fix the percentage of Health and Safety budget for the client to achieve the $\mathrm{OH} \& \mathrm{~S}$ target.

Also, Table 3 summarised the comment from the respondents about each element in OHSAS 18001. Through this, the improvement can be made, and the level of acceptance will be increased all parties to promote the atmosphere of safety culture towards sustainable construction in the Malaysian construction industry.

\subsection{Limitation of Study}

There were some limitations although the research has reached its aim. The data collected were mainly from the UiTM contractors only and not from all contractors in the Malaysian construction industry. Time constraints and the attitude of the respondents also contributed as the limitations of this study. 
Table 3: Comments to improve the OHSAS 18001

\begin{tabular}{|c|c|}
\hline ELEMENTS & COMMENTS \\
\hline $\begin{array}{l}\text { 1. Occupational } \\
\text { S\&H Policy }\end{array}$ & $\begin{array}{l}\text { - Provide the safety where emphasise the } \\
\text { responsibility and steps to improve the S\&H } \\
\text { at the work site. } \\
\text { - Revise the policy of this element and } \\
\text { examine the previous projects to improve } \\
\text { safety at the work site. }\end{array}$ \\
\hline 2. Planning & $\begin{array}{l}\text { - Suggest to respective subcontractor to } \\
\text { apply and implement planning flow by } \\
\text { OHSAS } 18001 \text {. } \\
\text { - All companies must establish a proper S\&H } \\
\text { based on Malaysian standard and must set } \\
\text { relevant objectives and it is measurable. } \\
\text { - Government also needs to formulate and } \\
\text { standardise a common programme for } \\
\text { everyone who importance in this industry. } \\
\text { - Identify clearly the new hazard at the work } \\
\text { site and create a new enforcement } \\
\text { produced by DOSH/JKKP. } \\
\text { - Revise this element based on suitability to } \\
\text { use it becomes easier for everyone. }\end{array}$ \\
\hline $\begin{array}{l}\text { 3. Implementation } \\
\text { \& Operation }\end{array}$ & $\begin{array}{l}\text { - All supervisors must be made mandatory to } \\
\text { be responsible for safety. } \\
\text { - All workers must be made mandatory to } \\
\text { attend the safety training. } \\
\text { - All supervisors must be made mandatory to } \\
\text { monitor on safety. } \\
\text { - Proper regulation on emergency } \\
\text { preparedness for all consultation industry } \\
\text { must be established. } \\
\text { - All companies must identify clearly the } \\
\text { training provided to their workers sufficient } \\
\text { enough and suitable. } \\
\text { - Ensure document controls are the } \\
\text { effectiveness of the next project to be } \\
\text { referred. } \\
\text { - Revise all each element of implementation } \\
\text { and operation becomes clear to everyone } \\
\text { especially Bumiputra contractors. }\end{array}$ \\
\hline $\begin{array}{l}\text { 4. Checking \& } \\
\text { Corrective } \\
\text { Action }\end{array}$ & $\begin{array}{l}\text { - All companies must be adopted on safety } \\
\text { and need to submit audit reports to DOSH. } \\
\text { - Suggest developing systems where } \\
\text { accidents will be immediately notified to } \\
\text { DOSH once reported to police and hospital. } \\
\text { - Make a compulsory for all companies to be } \\
\text { audited yearly. }\end{array}$ \\
\hline $\begin{array}{l}\text { 5. Management } \\
\text { Review }\end{array}$ & $\begin{array}{l}\text { - To make it as a compulsory in the law. } \\
\text { - Make analysis through the past accident, } \\
\text { previous report and all safety training were } \\
\text { conducted to ensure the management } \\
\text { review in always up-to-date. }\end{array}$ \\
\hline & $\begin{array}{l}\text { - The necessary information not only on } \\
\text { record/paper, but also on site situation and } \\
\text { evaluation. }\end{array}$ \\
\hline
\end{tabular}




\subsection{Conclusion}

The implementation of OHSAS 18001 in construction projects will support and portray a good impression on a safe environment for Malaysian contractors. It is hoped that it will further enhance the health and safety of Malaysian's projects by improving its operational efficiency through accident management reduction and lessening in downtime. Also, all parties need to understand and support the safety culture and risk to be taken in the project and comply with the regulation and safety management. Through this, a responsibility to promote the importance of OHSAS 18001 needs to be considered by all parties either by the government or private agencies. Furthermore, the tagline of "safety comes first" in construction projects needs to be absorbed in thoughts and the industry need to undertake and implement the OHSAS 18001 whether for small or large projects.

\section{Acknowledgment}

This paper was made for the Development Office UiTM and with the financial support of Development Office-Research Management Institute UiTM.

\section{References}

Ahmad, R.K. (2000), "Developing a Proactive Safety performance Measurement Tool (SPMT) for Construction Sites". University of Loughborough

Alashwal, M.T. (2008), "Safety cost in pre-cast concrete construction", Faculty of Civil Engineering, University of Technology Malaysia.

Bakri, A., Rosli Mohd Zin, R., Misnan, M.S., and Mohammed, A.H. (2006), "Occupational Safety and Health (OSH) Management Systems: Towards Development of Safety and Health Culture”, Proceedings of the 6th Asia-Pacific Structural Engineering and Construction Conference (APSEC 2006), 5 - 6 September 2006, Kuala Lumpur, Malaysia, Universiti Teknologi Malaysia.

Bashir, A.A. (2008),"Simulation safety management of IBS construction", Faculty of Civil Engineering, Universiti Teknologi Malaysia.

CIDB/CREAM IBS Survey (2010)," The critical success factors (CSFs) for the implementation of Industrialised Building System (IBS) in Malaysia, CIDB Malaysia

Dababneh, A. J. (2001), Effective Occupational Safety and Health Management System: Integration of OHSAS 18001, ILO-OSH 2001 and OR-OSHA Department of Industrial Engineering, Faculty of Engineering and Technology, University of Jordan

Davies, V. J. and Tomasin, K. (1996). Construction Safety Handbook. Thomas Telford.m

Department of Occupational Safety and Health (2004), Guidelines on First-Aid in Workplace, 2nd edition, Ministry of Human Resources, Malaysia.

ICMR Bulletin (2003), A national propriety of occupational health and safety management system, Vol.33, No.11-12 
Khalil, N., Husin, H.N. and Nawawi, A.H. (2012), Evaluation and concept of building performance towards sustainability in Malaysia higher institutions. Asian Journal of Environment-Behaviour Studies, Vol. 3,8, 27-39.

Langston, C.A. and Ding, G.K.C. (2001), Sustainable practices in the built environment, Langston, Butterworth-Heinemann, Oxford, 2001.

Miyatake Y. (1996), Technology development and sustainable construction , Journal of Management in Engineering, Vol. 12, No. 4, 1996, pp. 23 - 27.

Mohd Yunus, N.M., (2006), "Implementation of OHSAS 18001:1999: The experienced of construction companies in Malaysia", Universiti Teknologi MARA Shah Alam, Malaysia.

OHS Consultation (2002), Background information, Work cover NSW

OHSAS 18001:1999 Standard and its requirements Retrieved October 20, 2011, from https://docs.google.com/

OHSAS 18002:2000 (2000), Occupational health and safety management systems - Guidelines for the implementation of OHSAS 18001

Omran, A., Abu Bakar, A.H. and The, H.S., (2008), The Implementation of OHSAS 18001 in Construction Industry in Malaysia, School of Housing, Building and Planning, University Sains Malaysia, Journal of Engineering Annals Of Faculty of Engineering Of Hunedoara.

Overview of OHSAS 18001 Retrieved 1 October $11, \quad 2011$ from http://www.vts.net.my/OHSAS18001new.htm

Social Security Organisation (SOCSO) (2000), “Annual Report for 2000” Kuala Lumpur

Social Security Organization (SOCSO) (2005), Number of death cases reported from 2000-2004 Retrieved October, 20, 2011, from http://www.perkeso.org.my/statistik2.asp 